\title{
SERVICE MANAGEMENT AND GUEST SATISFACTION FOR THE HOTEL INDUSTRY IN ABEOKUTA, NIGERIA
}

\author{
Edwin Chigozie Nwokorie ${ }^{A}$ \\ Received: June 11, 2021 | Accepted: August 2, 2021 \\ DOI: 10.5937/ZbDght2101052C
}

\begin{abstract}
This study investigates the impact of service management on guest satisfaction in the hotel industry in five medium hotels in Abeokuta, Southwest Nigeria. A sample size of 154 was selected for the study, in which 102 usable responses were analyzed in inferential statistics for means and standard deviation. Pearson correlation, Analysis of Variance, and Ordinary List Squares were compared to measure relationships between variables through the formulated hypotheses for the study. Findings revealed a significant relationship between sufficient service management and guest satisfaction, while the relationship between guest goodwill and service management in the study area is not statistically significant. The study recommends the essentiality for the employer to provide adequate motivation to enhance workforce dedication to facilitate guest satisfaction.
\end{abstract}

Keywords: Employee motivation, guest satisfaction, hotel guest, service management, service quality.

\section{INTRODUCTION}

In recent times, there has been a surge in hotel business entrepreneurship in Ogun State, Southwest Nigeria. The business growth accounts for the increase in the establishment of hotel businesses in Abeokuta, the state's capital (and its environs), following massive development of road infrastructure by the state government (Nwokorie, Obiora, 2018). The hotel sector, arguably, plays an important role in the socio-economic growth of emerging societies. It is well-positioned as a major provider of decent paid accommodation for travelling businessmen. Due to the linkages it has with numerous sectors of the economy, it has the potency to create an array of jobs for the local population (Otu, Itam, Emeka, Eja, 2013). Studies have found out that service remains one of the major products of the hotel industry (Nwokorie, 2016; Tse, Ho, 2009; Mei, Dean, White, 1999). In the quest for quality service delivery for business success and growth, however, the performance of the hotel industry is dependent on a lot that connects with the sustenance of service quality to enhance guest satisfaction and loyalty. Hospitality management researchers believe that service management is a requirement for sustainable service delivery which inspires guest satisfaction, as studies indicate that getting quality service from the hotel is important to many guests (Joby, Grove, Fisk, 2006; Nickson, Baum, Losekoot, Marrison, Frochot, 2002).

A Department of Hospitality Management, School of Pure and Applied Sciences, The Federal Polytechnic Ilaro, Nigeria. Correspondence: edwin.nwokorie@federalpolyilaro.edu.ng 
Service management is an important concept for most service organizations (Nwokorie, Adeniyi, 2021; Gummesson, 1994) including hotel establishments. Service management is a concept that ensures the optimization of service delivery to customers while minimizing costs during the production process. The concept has to do with the adoption of a set of processes towards management, with a focus on customer needs, and continual improvement (Brenner, Garschhammer, Hegering, 2006).

In the hotel industry, quality service that satisfies guests is important to encourage them to revisit and to earn their satisfaction (Babajide, 2011) and loyalty (Carev, 2008) because customers only visit hotel establishments for some sort of solitude, and an awful experience could stop the customers from visiting again. Therefore, loyalty to the brand is very essential. So it is advised for hotels to do their best to provide the best services. A crucial characteristic of the hotel industry is the focus on guests' satisfaction (Darko, 2002). While guest satisfaction is common amongst other related organizations, the hotel industry relies entirely on keeping guests happy. Therefore, hotel establishments ensure that they hire employees based on their skills and behaviours to keep a satisfying employee-guest relationship and to flawlessly provide guests' needs.

To guarantee and preserve the quality expected by guests, hotel owners should design their quality of services to fit into the demands and needs of guests. Guests expect to have a 'home away from home' experience and if a hotel refuses to offer such services, guests are left dissatisfied. The dissatisfaction could result in guest turnover as well as a decrease in profits (Darko, 2002). Therefore, hotel employees must conform to the laid down service designs and ensure that guests are excellently satisfied.

One of the major perceived problems observed by previous researchers in the hospitality industry in some parts of Southwest Nigeria is the difference in quality service delivery by organizations in the hotel industry (Nwokorie, Adeniyi, 2021; Nwokorie, 2017; Nwokorie, Ezeibe, 2016). Nwokorie (2016) and Darko (2002) viewed that price level turns to be similar in total operations when competition causes organizations to expand, so managing the quality of service becomes the key factor differentiating competitors in the expansion regime and price war. The implication is that most firms only increase the prices of the services offered while neglecting the consideration to provide service quality, which leads to the inability of hotel owners to provide and sustain guest satisfaction. Due to these reasons, this study evaluates the impact of service management on guest satisfaction in selected hotels in Abeokuta, Nigeria. The study is employed to identify what service management means and how it is structured and point out how guests and guest contact personnel recognize the manifestation of service management of the selected hotels. The study is very important because it will help in revealing the impact of service management on the hotel establishments in the study area.

With the high increase of hotel establishments and the need to provide distinct services for guests' satisfaction, there have been accompanying demands for hotel owners to adopt appropriate service management procedures. While most hotels are known for providing excellent and efficient services, some of the traditional concepts of services rendered are inadequate in solving the problems faced by hotel businesses in guest satisfaction around the study area (Nwokorie, 2016).

Hotel establishments are lagging in the management of services due to various reasons that are identified in previous studies, including customer aggression and poor guest feedback mechanism (Nwokorie, 2017; Nwokorie, 2016; Nwokorie, Ezeibe, 2016). This study is therefore devoted to enlightening hotel owners on the impact of service management as well as providing means of solving the setbacks.

Consequently, the key objective of the study is to identify the impacts of service management on guests' satisfaction in selected hotels in Abeokuta, Nigeria. The specific objectives are to:

a) Examine the relationship between employee motivation and quality service delivery.

b) Examine the relationship between quality service delivery and guest satisfaction

c) Examine the relationship between service management and guest goodwill 


\section{LITERATURE REVIEW}

Service quality can be seen as a perception resulting from an attitude formed by a consumer's long-term overall performance evaluation (Nwokorie, Adeniyi, 2021; Hassan, Hassan, Nawaz, Aksel, 2013). One of the key objectives of every service organization is to deliver quality services to the customer from time to time. So, having the ability of quality service delivery by a service provider is viewed as an indispensable approach for business survival and success in a competitive business atmosphere. Therefore, the service encounter is an essential part of the service delivery process because it influences the customers' evaluation of consumption experiences in the servicescape (Zeithaml, Bitner, Dwayne, 2013). Several studies have been carried out concerning the service encounter centred on the belief of a causal association of service quality, the service encounter, and customer perception.

The hospitality industry is a sector of the service industry, with a relatively high level of personal contact between employees and guests. Most often, the quality of the service encounter is measured by the duration of the contact between the employee and the guest. The duration implies adequate attention needs to be focused on the efficient management of the interaction that may influence service quality in the hotel environment which may affect sales (Zeithaml, Parasuraman, Berry, 1990). As a result, the "moment of truth" or service encounter has become an important philosophy in the hospitality industry. While considerable research has been conducted in the service sector in general, focusing on service encounter (Lemmink, Mattsson, 2002; Bebko, 2001; Sundaram, Webster, 2000; Mattila, 1999; Price, Arnould, Deibler, 1994), specific concern in managing service encounters in hospitality organizations has received very little attention. It is imperative, therefore, to further explore strategic processes for service quality through managing the service encounters for hotel establishments.

\section{Concept of Service Quality}

For the hotel industry, service quality is what the guest makes of it (Jomnonkwao, Champahom, Ratanavaraha, 2020). So, service quality is what the guest says it is. Unfortunately, most service enterprises define quality service from the perspective of what they produce and judging from the appearance of the product. Nwokorie and Adeniyi (2021) and Grönroos (2005) identified the technical and functional components of service quality based on customer perception. While technical quality represents the result of a service production process, functional quality represents the experience of the customer throughout the process of service consumption. Technical quality is generated through the tangible dimensions while functional quality is generated through the intangible dimensions of the service encounter. For example in a restaurant setting, the delicious food served to the guest is the technical quality of service, while the manner the guest is treated and served by the waiter is the functional quality. Both situations influence customer perception of service quality.

\section{Service Management in the Hospitality Industry}

There seems to be a common belief, in literature, that providing customer satisfaction is a function of providing quality service. Nwokorie and Adeniyi (2021), Nwokorie (2016), Parasuraman, Zeithaml and Berry (2006a), Grönroos (2005), and Johnston and Morris (1985) described service quality from the customer satisfaction point of view; as the level of agreement between customers' expectations and delivery of service. Some other scholars tried being more specific on the issue of service quality measurement. While Smith (1982) supported the notion that service quality is difficult to quantify, and identifies measures used in manufacturing firms, Voss (2006) believed in the intangibility of the service packages which are most difficult to measure, and agrees that service quality tends to be ignored, consequently. Kaplan (2003) believes that there is a tendency to measure only what is easily quantifiable for the manufacturing industry (like financial performance and productivity) even though 
other aspects such as quality, innovation, and flexibility may be crucial to a company's competitive success. But, the tourism industry deals with less tangible outcomes than manufacturing or agriculture.

Still, scholars agree to the possibility of a hard or soft measure of service quality. While the hard measure is concerned with quantifiable outcomes like percentage of time spent on customer care through the telephone, for instance, the soft measure is more qualitative and judged in terms of guest satisfaction with the speed of service, and are more appropriate in measuring the quality of intangible aspects of service.

Information on service quality can be assembled from internal and external data sources, according to Silvestro, Johnston, Fitzgerald and Voss (2004). Managers and employees of an organization could generate internal data from within the establishment to help the firm understand how well it is meeting up with service quality based on the firm's philosophy. Although internal data generation may not broadly define the value of service quality and customer satisfaction if the firm has no other means of internal assessment for customer satisfaction (Nwokorie, 2016). Silvestro et al. (2004) noted that customers also assess the quality of the service throughout the service encounter, resulting in a certain satisfaction level. Consequently, hotels can assess service quality by measuring customer satisfaction with external data. Whilst the measurement of service quality perceptions is now prevalent in tourism and hospitality, it is imperative to put the perspective of guest expectation in the service encounter in the business plan.

The job of service providers has been described by Gong, Park and Hyun (2020), Yoo, Back and Park (2019), and Hochschild (2003) as emotional labour. This involves the service employee empathizing with both the guest who pays for the service, and the goals of the organization (the employer). Hochschild, especially, saw service encounter as the advertising of human emotions, in which caution is necessary to mitigate negative social outcomes. For Klaus (2006), service encounter involves the delivery of responsibilities ceremonially. Behaviours in delivering the tasks are interconnected while the elements of the ceremonial manner of the encounter should be psychologically charged to generate satisfaction from the purchaser of the service.

While describing the service encounter, McCallum and Harrison (2006) carefully applied the theory of social interdependence. The theory holds that the conduct of an individual has a corresponding effect on the results received by the other individual in an interaction. The theory suggests a basis for analysis in harmonizing interdependence existing in the relationship. Relatively, Czepiel (2000) noted that control of market share and organizational strategy are vital for the harmonization of interdependence in service relationships.

\section{Service Failure in the Hotel Industry}

Service failure occurs at the 'moment of truth' or in the service encounter when customers interact with service personnel. The failure is quite rampant in service delivery processes in various hotel establishments due to the inability of the hotels to provide adequate quality of service to customers (Nwokorie, Ezeibe, 2016; Hassan et al., 2013). When such failures occur, it is quite important to provide the service personnel with the tools necessary to correct them because the timeliness and form of response by service providers to service failure will have a direct impact on customers' satisfaction and quality perceptions (Nwokorie, Ezeibe, 2016; Joby et al., 2006).

Service failure could be a result of normally available services being unavailable, unreasonably slow services, and other related failures in the industry. For example, an air-conditioning system in a hotel room may have become faulty and repairs may have not been carried out before assigning the room to a guest, or a front desk operator being inactive or slow when attending to customers who need to be in their rooms as early as possible. When such failures arise, it is necessary to provide a quick recovery plan so as not to leave the guest disappointed (Nwokorie, 2016; Nwokorie, Ezeibe, 2016).

When dealing with failures in the hotel system, one of the major recovery plans or strategies is to actively encourage complaints (Nwokorie, 2016). It is necessary to listen to customers air their dissatisfaction regarding service so that a quick response and effective improvement can be made. The cost of losing a customer and obtaining new ones is quite large when compared to the benefit of keeping existing ones (Hassan et al., 2013). 


\section{Theoretical Framework}

Role theory was employed by Solomon, Bamossy, Askegaard and Hogg (2006) to discover the behaviour of individuals in the service encounter. Most service interactions tend to be standard and social relationships, in which there are clearly defined roles between the guest and the service provider, with a cautiously detailed character. From the social relationship point of view, guest satisfaction and service effectiveness are a function of role clarity. So, the quality of agreement between the parties concerning the suitability of roles could be influenced by the level of understanding of the scope of role congruence and expectation between the parties. Job satisfaction also plays a role in how service providers understand their role in the encounter (Ford, Walker, Churchill, 2008; Oliver, 1993) same way as role incompatibility (Schneider, Pichora-Fuller, 2000). The significance of service standards has been found by Czepiel (2000) to be the result of role theory, as McCallum and Harrison (2006) also examined the positive impact of content and elegance in the service encounter on the assessment of service quality on customer satisfaction. The authors revealed that 'programmed personalization' in the service encounter diminished customers' evaluations of service personnel and company-level fundamental exchange elements like trust, effectiveness, and competence.

\section{Conceptual Framework}

Every manager in the hotel industry claims to have a natural understanding of quality. Still, quality has been found difficult to be defined and applied. The major problem could be attributed to the failure of actually defining quality from the point of view of hospitality products and services, which have been mistaken for the traditional connotation of quality (in the sense of product quality) associated with ostentation and perceived excellence (Grönroos, 2005). But, Nwokorie (2016) believes that quality should be treated as a major function and component of hospitality resources. Grönroos (2005) condemns suggesting quality as a mere variable, but should rather be incorporated in the range of activities for service delivery, while Parasuraman, Zeithaml, and Berry (2006b) agree that many scholars have erroneously presented quality as an indefinable and unclear concept.

The studies of Parasuraman et al. (2006b) and Grönroos (2005) exposed the attempt by some scholars to develop a framework for empirical evidence for anticipated and consequent satisfaction from hospitality products and services. Nwokorie (2016) and Lewis and Sauro (2009) have researched hotel customer service and customer satisfaction. Their studies refer to consumer gaps, while Blake, Dexheimer and Mercurin (2001) referred to differences as disparity analysis. From the theoretical perspective, however, a great deal of research is yet to be carried out on satisfaction through hospitality services. Therefore, exploring the basic philosophies of service management and guest satisfaction from the point of view of hospitality services is imperative.

\section{Impact of Service Management on Guests Satisfaction}

The impact of quality service or adequate service management on guest satisfaction should not be underemphasized because 'a satisfied guest is a happy guest.' When guests are not satisfied, a major setback could arise leading to adverse effects on the reputation of the hotel (Nwokorie, 2016). When customers complain, they expect positive feedback from the firm. Therefore, hotels must present a recovery strategy that will enhance customer satisfaction in the establishment.

Guests tend to repeat patronage when they are satisfied (Nwokorie, Igbojekwe, 2019; Joby et al., 2006). Repeating business means advertising the hotel products and services to other people which increases sales. A high level of satisfaction is associated with a higher percentage of repeat customers and these customers become extremely loyal to the establishment (Tse, Ho, 2009).

Profits will be highly generated in the establishment which provides effective quality service and this will help in boosting the local economy through paid taxes and other fees (Nwokorie, Adiukwu, 2020). Employees 
will also be paid on time to encourage them to want to perform better, thus helping the establishment to survive in the competitive environment.

High-level guest satisfaction will result in the building of a good reputation of the hotel (Nwokorie, 2020; Purohit, Purohit, 2013; Tatikonda, 2013). Guests tend to discuss their perception of services offered in a hotel to people they are quite close to who, in turn, discuss it with other people (Nwokorie, Adeniyi, 2021; Hassan et al., 2013). If poor quality service is being offered, a bad reputation is being built (Nwokorie, 2020). This could result in loss of customers, hence reduced profits. On the contrary, delivery of effective, efficient, and quality service leads to the development of a good reputation for the establishment, and high revenue from customers which translate to increased profit (Joby et al., 2006).

\section{Motivation and Service Delivery}

While productivity is a viable component of quality products which is, unarguably, the genesis of quality service delivery (Çetin, 2013), it is important to understand the role of employee motivation in the service encounter. Quality service delivery is a function of the performance of employees, which hugely depends on their motivation level. Nwokorie (2020) and Marshall, Mottier and Lewis (2015) emphasized that a motivated employee performs optimally and assists the organization to retain a leading position in the competitive business environment.

Nwokorie and Adiukwu (2020), Nwokorie and Aneke (2019), and Çetin (2013) also observed that business organizations use encouragement tools to enhance employee productivity, especially when competition heightens and employees are tempted with better offers from other establishments. Fitsum (2018) found out that employee performance in the hotel industry is a function of the level of motivation from management. Similarly, Bello and Bello (2017) discovered a positive statistical relationship between employees' empowerment, service quality, and customer satisfaction in hotel establishments. Their study saw that "empowering employees supports the development of intrinsic capability, and self-determination, hence assisting employees to deliver on the enterprise mandate of providing quality service" (Bello, Bello, 2017, p.1013). These indices point to the fact that customer contact employees would need some sort of sustained motivation to deliver and manage the service encounter effectively towards guest satisfaction and organizational efficiency.

\section{Hypotheses for the Present Study}

Three null hypotheses were stated for the study in line with the study objectives for credence purposes. The hypotheses are:

$\mathrm{H}_{1}$ : There is no relationship between employee motivation and quality service delivery

$\mathrm{H}_{2}$ : There is no relationship between quality service delivery and guest satisfaction

$\mathrm{H}_{3}$ : There is no relationship between service management and guest goodwill.

\section{METHODOLOGY}

The study adopts the correlational research procedure to examine the relationship between the consequent variables of service management and guest satisfaction for the selected hotels in Abeokuta, Nigeria. The convenience sampling method was used to select five medium-sized hotels that allowed access to the study. The population of the study was made up of 250 customer contact employees and guests in the hotels. Since the entire population could not be covered, a sample of 154 was calculated with the Taro Yamane formula for sample size determination (Yamane, 1967). 
Data were collected with a 24-point structured survey instrument (questionnaire) as the primary source. The instrument was divided into two sections. The first section deals with demographic details of the respondents while the second section contains research statements postulated in line with the research objectives, with options provided (in a Likert scale) for each response.

The principal component analysis was used to minimize the dimensionality of the datasets, as well as achieve their increased interpretability and minimize data loss. Results from PCA have the following extracts:

1. Employee motivation (EM)
a) Guest security

2. Quality of service delivery (QSD)
a) Anxiety over service delivery
b) Electronic payment system
c) Electronic reservation and booking
d) Flexible tariff

3. Guest satisfaction (GS)
a) Anxiety over service delivery
b) Dedicated workforce
c) Electronic reservation and booking
d) Regular energy supply

4. Service management (SM)
a) Scheduled maintenance of equipment
b) Improved customer base

5. Guest goodwill (GG)

a) Positive word-of-mouth

Data were analyzed in inferential statistics for means and standard deviation. The ordinary least square (OLS) method, Analysis of Variance (ANOVA), Pearson Correlation regression analysis were employed to test hypotheses and determine relationships between the consequent variables of the study. These analytical tools are necessary for conclusions by collecting the observed values from the research instrument, testing the degree of freedom, and carrying out a decision in determining the critical values of the hypotheses.

\section{RESULTS}

Results are presented in three parts. First, the demographic variables of the respondents are presented. The second part is concerned with the description of the statements contained in the questionnaire, while the third part is concerned with the test of hypotheses for the study. A total of 154 research instrument were administered to respondents, in which $71.43 \%$ (110) response rate was recorded and found suitable for analysis. The response rate is adequate for analysis as Evans, Peterson and Demark-Wahnefried (2004) viewed that a $60 \%$ response rate is acceptable for data analysis for most studies. However, eight unusable questionnaires were removed, leaving the number of usable questionnaires at 102 , which represents $66.23 \%$ of the total questionnaire distributed and $92.73 \%$ of total questionnaires returned.

Table 1. Reliability Analysis

\begin{tabular}{|c|c|c|}
\hline Cronbach's Alpha & Valid Number & Number of Items \\
\hline 0.775 & 102 & 19 \\
\hline
\end{tabular}

Source: Data output. 
The reliability of the research instrument shows a Cronbach's alpha of 0.775 . The result indicates reliability for the research instrument, and data therefrom can further be analyzed to obtain results and draw conclusions for the study.

\section{Findings}

Table 2: Demographic information of respondents

\begin{tabular}{|c|c|c|c|c|c|}
\hline $\mathrm{S} / \mathrm{N}$ & $\begin{array}{l}\text { Item № (in research } \\
\text { instrument) }\end{array}$ & Statement & Respondents & Sample (n) & $\%$ \\
\hline \multirow[t]{2}{*}{1} & \multirow[t]{2}{*}{1} & \multirow[t]{2}{*}{ Gender } & $\begin{array}{l}\text { Male } \\
\text { Female }\end{array}$ & $\begin{array}{l}32 \\
70\end{array}$ & $\begin{array}{l}31.4 \\
68.6\end{array}$ \\
\hline & & & & 102 & 100 \\
\hline \multirow{6}{*}{2} & \multirow{6}{*}{2} & \multirow{6}{*}{ Age } & $18-25$ & 20 & 19.6 \\
\hline & & & $26-35$ & 12 & 11.8 \\
\hline & & & $36-45$ & 70 & 68.6 \\
\hline & & & $46-65$ & - & - \\
\hline & & & 66 and above & - & - \\
\hline & & & & 102 & 100 \\
\hline \multirow{5}{*}{3} & \multirow{5}{*}{3} & \multirow{5}{*}{$\begin{array}{l}\text { Educational } \\
\text { Qualification }\end{array}$} & ND/NCE & 18 & 17.7 \\
\hline & & & HND/BSC & 80 & 78.4 \\
\hline & & & M.Sc./MBA & 4 & 3.9 \\
\hline & & & Others & - & - \\
\hline & & & & 102 & 100 \\
\hline \multirow{4}{*}{4} & \multirow{4}{*}{4} & \multirow{4}{*}{$\begin{array}{l}\text { Experience/ } \\
\text { Year of Service }\end{array}$} & 01-05 & 80 & 78.4 \\
\hline & & & $06-10$ & 22 & 21.6 \\
\hline & & & Above 10 & - & - \\
\hline & & & & 102 & 100 \\
\hline \multirow{5}{*}{5} & \multirow{5}{*}{5} & \multirow{5}{*}{ Hours of Work per day } & 12 & 70 & 68.6 \\
\hline & & & 08 & 17 & 16.8 \\
\hline & & & 07 & 13 & 12.8 \\
\hline & & & 06 & 2 & 2 \\
\hline & & & & 102 & 100 \\
\hline
\end{tabular}

Source: Data output.

Demographic details of respondents show that 32 (31.4\%) respondents are males and $70(68.6 \%)$ are females, which indicates that more females are involved in the study. In addition, 20 (19.6\%) of these respondents are 18-25 years, 12 (11.8\%) are 26-35 years, and the rest are 36-45 years of age. While 18 (17.7\%) have ND/ NCE certificates, 80 (78.4\%) have HND/BSc certificates and the remaining have MSc/MBA certificates. Moreso, $80(78.4 \%)$ have worked up to five years in service of the hotel and $22(21.6 \%)$ have worked over five years on the job. Up to $70(68.6 \%)$ respondents affirmed to work up to 12 hours per day, 17 (16.6\%) respondents work for eight hours per day, 13 (12.8\%) respondents also confirmed they work seven hours per day, and the remaining $2.0 \%$ affirmed they work up to 6 hours per day (Table 2). 
Table 3: Service Management and Improvement

\begin{tabular}{|c|c|l|c|c|c|c|c|c|}
\hline S/N & $\begin{array}{c}\text { Item No (in research } \\
\text { instrument) }\end{array}$ & Statement & SA (\%) & A (\%) & $D(\%)$ & SD (\%) & $\overline{\mathbf{x}}$ & $\sigma \overline{\mathbf{x}}$ \\
\hline 1 & 6 & Improved inventory system & $79(77.5)$ & $23(22.5)$ & - & - & 3.82 & .341 \\
\hline 2 & 7. & $\begin{array}{l}\text { Scheduled maintenance of } \\
\text { equipment }\end{array}$ & $22(21.6)$ & $80(78.4)$ & - & - & 3.58 & .651 \\
\hline 3 & 8. & Anxiety over product availability & $55(53.9)$ & $47(46.1)$ & - & - & 3.79 & .432 \\
\hline 4 & 9. & Affordable competitive price & $50(49)$ & $30(29.4)$ & $22(21.6)$ & - & 3.48 & .731 \\
\hline 5 & 10. & Anxiety over services bought & $56(54.9)$ & $16(15.7)$ & $30(29.4)$ & - & 3.34 & 1.345 \\
\hline 6 & 11. & $\begin{array}{l}\text { Capacity to improve on present } \\
\text { operation level }\end{array}$ & $44(43.1)$ & $58(56.9)$ & - & - & 3.58 & .321 \\
\hline 7 & 12. & Dedicated workforce & $40(39.2)$ & $62(60.8)$ & - & - & 3.56 & .420 \\
\hline 8 & 13. & Periodic training on quality service & $46(45.1)$ & $41(40.2)$ & $15(14.7)$ & - & 3.55 & .520 \\
\hline 9 & 14. & $\begin{array}{l}\text { Improved customer base - Past 14 } \\
\text { months }\end{array}$ & $39(38.2)$ & $45(44.1)$ & $18(17.7)$ & - & 3.63 & .433 \\
\hline
\end{tabular}

Source: Data output.

$n=102 ;$ Codes: $S A=$ Strong Agreement; $A=$ Agreement; $D=$ Disagreement; $S D=$ Strong Disagreement; $\bar{x}=$ Mean Score; $\sigma \bar{x}=$ Standard Error.

Responses on service management and improvement presented in Table 3 (and Figure 1) indicate that 79 (77.9\%) and $23(22.5 \%)$ of the respondents are in agreement that the establishment has improved the inventory system. Similarly, 22 (21.6\%) and 80 (78.4\%) respondents attested to the scheduled maintenance of equipment by the establishments. On the concern of service outlets about product availability, 55 (53.9\%) and 47 (46.1\%) respondents agreed that the outlets are always anxious about product availability. Also, 50 (49\%) respondents strongly agreed that their price is affordable compared to other competitors, 30 (29.4\%) respondents also agreed with the statement, and the remaining 22 (21.6\%) disagreed with the statement. Further, 56 (54.9\%) respondents strongly agreed, $16(15.7 \%)$ respondents strongly agreed and the remaining 30 (29.4\%) disagreed with the statement that product suppliers are always anxious about payments after service has been rendered. Moreover, all the respondents affirmed that the establishments can improve on the present level of operation. It was also observed that $40(39.2 \%)$ and $62(60.8 \%)$ respondents strongly agreed and agreed that the establishments have a dedicated workforce. Up to 46 (45.1\%) strongly agreed with the statement that they are periodically trained, 41 (40.2\%) respondents agreed with the statement, and the remaining 15 (14.7\%) disagreed. Lastly, 39 (38.2\%) respondents strongly agreed that the customer base has improved in the last 14 months and 45 (44.1\%) of the respondents also affirmed to the statement. The summary of the analysis shows that the average response to each of the statements is favourable since there is no average below 3.0 and the standard deviation is an indication of less deviation in the responses.

Table 4: Dimensions of Service Quality

\begin{tabular}{|c|c|l|c|c|c|c|c|c|}
\hline S/N & $\begin{array}{c}\text { Item No (in research } \\
\text { instrument) }\end{array}$ & Statement & SA (\%) & A (\%) & D (\%) & SD (\%) & $\overline{\mathbf{x}}$ & $\sigma \overline{\mathbf{x}}$ \\
\hline 1 & 15. & Guest security. & $73(71.6)$ & $29(28.4)$ & - & - & 3.84 & .495 \\
\hline 2 & 16. & Guest-friendly processes. & $65(63.7)$ & $37(36.3)$ & - & - & 3.76 & .695 \\
\hline 3 & 17. & Guest value. & $42(41.2)$ & $60(58.8)$ & - & - & 3.75 & .340 \\
\hline 4 & 18. & Electronic payment system. & $63(61.8)$ & $39(38.2)$ & - & - & 3.81 & .768 \\
\hline 5 & 19. & Electronic reservation and booking. & $30(29.4)$ & $63(61.8)$ & $9(8.8)$ & - & 3.78 & .390 \\
\hline 6 & 20. & Flexible tariff. & $53(52)$ & $49(48)$ & - & - & 3.72 & .384 \\
\hline 7 & 21. & Customer care unit. & $42(41.2)$ & $60(58.8)$ & - & - & 3.84 & .541 \\
\hline 8 & 22. & Regular energy supply. & $38(37.3)$ & $64(62.7)$ & - & - & 3.77 & .646 \\
\hline 9 & 23. & Regular internet service. & $6(5.9)$ & $96(94.1)$ & - & - & 3.58 & .347 \\
\hline 10 & 24. & Positive word-of-mouth & $57(55.9)$ & $45(44.1)$ & - & - & 3.82 & .312 \\
\hline
\end{tabular}

Source: Data output. 


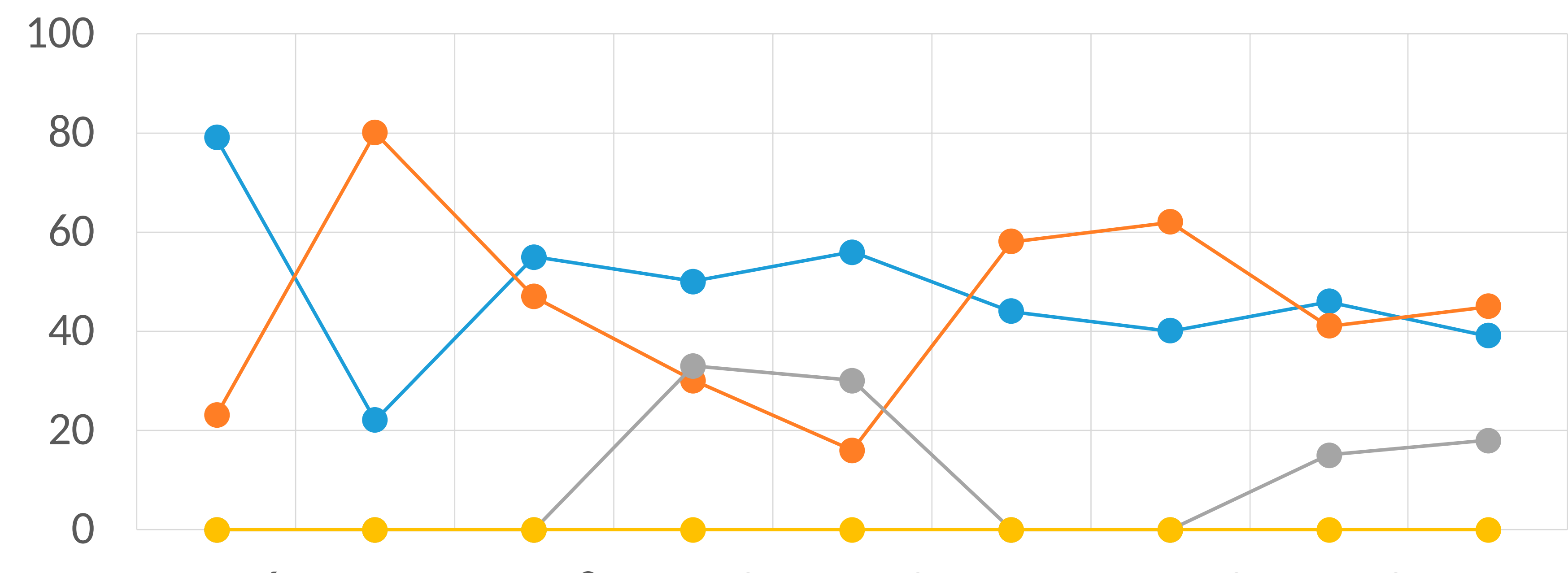

ITEM 6 ITEM 7 ITEM 8 ITEM 9 ITEM 10 ITEM 11 ITEM 12 ITEM 13 ITEM 14

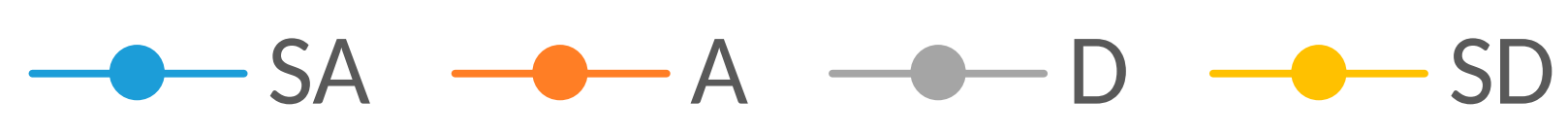

Figure 1: Plot for Service Management and Improvement

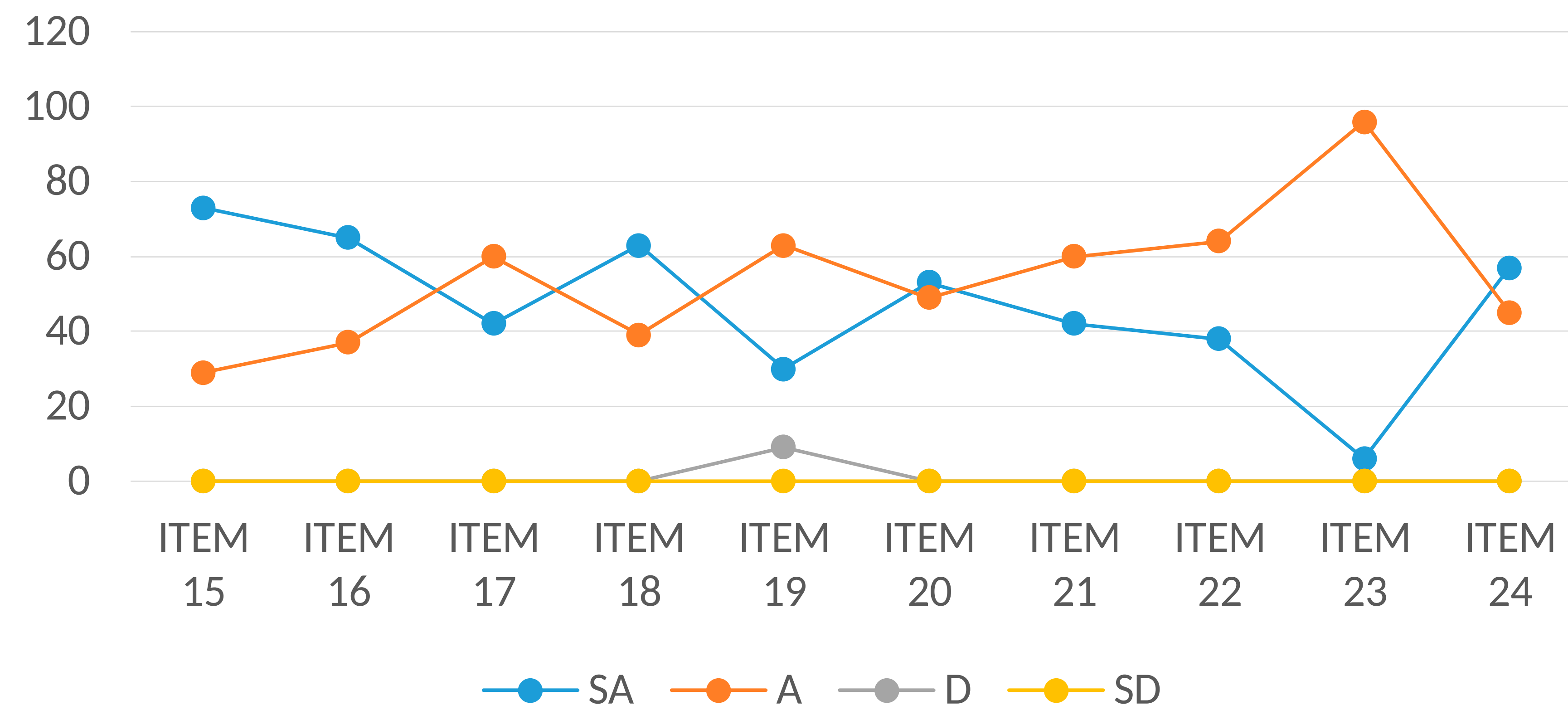

Figure 2: Plot for Dimensions of Service Quality

Summary of the responses on dimensions of service quality revealed that $73(71.6 \%)$ and $29(28.4 \%)$ respondents strongly agreed and agreed that guests feel secure in the hotel. Also, 65 (63.7\%) and 37 (36.3\%) respondents affirmed that service processes/methods are customer-friendly, as they strongly agreed and agreed accordingly. In addition, 42 (41.2\%) respondents strongly agreed and 60 (58.8\%) agreed that their hotel places optimum value on guests. On whether there is a provision of an electronic payments system, 63 (61.8\%) and 39 (38.2\%) respondents strongly agreed and agreed that there is a provision for an electronic payments system. Also, respondents were asked whether customers can make reservations/bookings electronically, 30 (29.4\%) respondents strongly agreed with the statement, and $63(61.8 \%)$ respondents equally agreed. All the respondents affirmed that there is the availability of tariffs to suit different guests' demands. Still, 42 (41.2\%) strong agreements and 60 (58.8\%) agreements were recorded on having customer care units in the establishments. On the availability of regular energy supply, 38 (37.3\%) respondents strongly agreed that there is a regular supply of energy and the remaining respondents agreed to the statement. As many as 96 (94.1\%) respondents agreed that there is regular availability of internet facilities for the guests and the remaining respondents strongly agreed with the statement. Lastly, 57 (55.9\%) respondents strongly agreed that the establishments enjoy positive word-of-mouth advertisement from guests, and the remaining $44.1 \%$ of the respondents also agreed with the statement. The average response shows mean scores greater than 3.0 which indicates the responses are in favour of the statement and the respective standard deviation indicates minimum deviations (Table 4, Figure 2). 


\section{Principal Component Analysis Summary}

Data were summarized through a data reduction process (principal component analysis) to get variables to test hypotheses. Variables for the test of hypotheses, with the total number of statements in the questionnaire that could be used for testing each of the variables, are indicated. The extracted items for the analysis (EM, QSD, GS, SM, and GG) were measured using an ordinal scale because they are qualitative data. The measurement assisted in comparing the items for variations. However, after data reduction was done, with eigenvalues of more than one (1) as the standard for selecting the variables; it was discovered that only one item out of the two could be used for employees' motivation (EM) because this item explains about 63\% variation in the responses of the sample. Similar observations were made for quality of service delivery (QSD), guest satisfaction (GS), service management (SM), and guest goodwill (GG) with; four items representing eight items that could be used for quality of service delivery with $73 \%$ cumulative variance; four items representing 10 items that could be used for guest satisfaction with $68 \%$ cumulative variance; two items representing five items that could be used for service management with $66 \%$ cumulative variance; and one item representing two items that could be used for guest goodwill with $69 \%$ cumulative variance respectively (Table 5).

Table 5. Principal Component Analysis

\begin{tabular}{|l|l|c|c|c|}
\hline S/N & Variable & Total Item & Extracted Item & Cumulative Variance \% \\
\hline 1. & Employees' Motivation (EM) & 2 & 15 & 63 \\
\hline 2. & Quality of Service Delivery (QSD) & 8 & $8,18,19,20$ & 73 \\
\hline 3. & Guest Satisfaction (GS) & 10 & $8,12,19,22$ & 68 \\
\hline 4. & Service Management (SM) & 5 & 7,14 & 66 \\
\hline 5. & Guest Goodwill (GG) & 2 & 24 & 69 \\
\hline
\end{tabular}

Source: Data output.

\section{Correlational Tests}

Table 6. Correlations, ANOVA and OLS

\begin{tabular}{|c|c|c|c|c|c|c|}
\hline \multicolumn{7}{|c|}{$\mathrm{H}_{1}$ Correlation between EM and QSD } \\
\hline Variable & Pearson Correlation & \multicolumn{2}{|l|}{ R-Square } & Std. Error of the Estimate & \multicolumn{2}{|l|}{ Sig. (2-tailed) } \\
\hline$E M-Q S D$ & -0.694 & \multicolumn{2}{|l|}{0.482} & 1.096 & \multicolumn{2}{|l|}{0.028} \\
\hline \multicolumn{7}{|c|}{$\mathrm{H}_{1}$ ANOVA } \\
\hline Model & & Sum of Squares & $d f$ & Mean Square & $\mathrm{F}$ & Sig. \\
\hline \multirow[t]{3}{*}{1} & Regression & 11.618 & 1 & 11.618 & 9.666 & $.028 b$ \\
\hline & Residual & 181.441 & 151 & 1.202 & & \\
\hline & Residual & 181.441 & 151 & 1.202 & & \\
\hline \multicolumn{7}{|l|}{$\mathrm{H}_{1} \mathrm{OLS}$} \\
\hline Model & Coefficients & \multicolumn{2}{|l|}{ Std. Error } & t-value & \multicolumn{2}{|l|}{ Sig. value } \\
\hline $\begin{array}{l}\text { Constant } \\
\text { EM }\end{array}$ & $\begin{array}{c}14.972 \\
-0.806\end{array}$ & \multicolumn{2}{|l|}{$\begin{array}{l}0.624 \\
0.177\end{array}$} & $\begin{array}{l}23.989 \\
4.554\end{array}$ & \multicolumn{2}{|l|}{$\begin{array}{l}0.00 \\
0.028\end{array}$} \\
\hline \multicolumn{7}{|c|}{$\mathrm{H}_{2}$ Correlation between GS and QSD } \\
\hline Variable & Pearson Correlation & \multicolumn{2}{|l|}{ R-Square } & Std. Error of the Estimate & \multicolumn{2}{|l|}{ Sig. (2-tailed) } \\
\hline GS - QSD & 0.543 & \multicolumn{2}{|l|}{0.295} & 0.922 & \multicolumn{2}{|l|}{0.000} \\
\hline \multicolumn{7}{|c|}{$\mathrm{H}_{2}$ ANOVA } \\
\hline Model & & Sum of Squares & $d f$ & Mean Square & $\mathrm{F}$ & Sig. \\
\hline 2 & Regression & 53.752 & 1 & 53.752 & 63.186 & $.000 b$ \\
\hline
\end{tabular}




\begin{tabular}{|c|c|c|c|c|c|c|}
\hline & Residual & 128.457 & 151 & .851 & & \\
\hline & Total & 182.209 & 152 & & & \\
\hline \multicolumn{7}{|l|}{$\mathrm{H}_{2} \mathrm{OLS}$} \\
\hline Model & Coefficients & \multicolumn{2}{|l|}{ Std. Error } & t-value & \multicolumn{2}{|l|}{ Sig. value } \\
\hline $\begin{array}{l}\text { Constant } \\
\text { QSD }\end{array}$ & $\begin{array}{l}6.347 \\
.542\end{array}$ & \multicolumn{2}{|l|}{$\begin{array}{l}0.975 \\
0.068\end{array}$} & $\begin{array}{l}6.513 \\
7.949\end{array}$ & \multicolumn{2}{|l|}{$\begin{array}{l}0.000 \\
0.000\end{array}$} \\
\hline \multicolumn{7}{|c|}{$\mathrm{H}_{3}$ Correlation between GG and SM } \\
\hline Variable & Pearson Correlation & \multicolumn{2}{|l|}{ R-Square } & Std. Error of the Estimate & \multicolumn{2}{|l|}{ Sig. (2-tailed) } \\
\hline$S M-G G$ & 0.311 & \multicolumn{2}{|l|}{0.0967} & .503 & \multicolumn{2}{|l|}{0.332} \\
\hline \multicolumn{7}{|c|}{$\mathrm{H}_{3}$ ANOVA } \\
\hline Model & & Sum of Squares & df & Mean Square & $\mathrm{F}$ & Sig. \\
\hline \multirow[t]{3}{*}{3} & Regression & .037 & 1 & .037 & 0.147 & $.332 b$ \\
\hline & Residual & 38.198 & 151 & .253 & & \\
\hline & Total & 38.235 & 152 & & & \\
\hline \multicolumn{7}{|l|}{$\mathrm{H}_{3} \mathrm{OLS}$} \\
\hline Model & Coefficients & \multicolumn{2}{|l|}{ Std. Error } & t-value & \multicolumn{2}{|l|}{ Sig. value } \\
\hline $\begin{array}{l}\text { Constant } \\
\text { SM }\end{array}$ & $\begin{array}{l}3.360 \\
.022\end{array}$ & \multicolumn{2}{|l|}{$\begin{array}{l}0.393 \\
0.057\end{array}$} & $\begin{array}{l}8.557 \\
0.384\end{array}$ & \multicolumn{2}{|l|}{$\begin{array}{l}0.000 \\
0.332\end{array}$} \\
\hline
\end{tabular}

Source: Data Output

\section{DISCUSSION}

Results have shown the level of involvement of the selected establishments of the study in managing service. The majority of the responses were recorded in favour of improved inventory control. An improved inventory management system helps hotel establishments prevent losses of materials, with cost-effective solutions to improve organizational efficiency (Nwokorie, Adiukwu, 2020; Aluri, Munnanji, 2011), improved supplier management, and adequate procurement planning (Abuya, Shale, 2018), which are necessary for service recovery (Nwokorie, 2016)

Scheduled equipment maintenance, which is important for avoiding service breakdown, was positively indicated in the study. Ghazi (2016) found out that lack of equipment maintenance is a major barrier to efficient service delivery in the hotel industry.

Respondents attested to anxiety over product availability. Fulfillment of such anxiety is key to customer loyalty in service operations (Bello, Bello, 2017; Nwokorie, 2016). Affordable competitive price was equally indicated in the study for the establishments. Pricing strategies could be used by hotels to improve revenue generation, gain competitive advantage and market share, leading to continuous improvement (Nwokorie, 2017).

As the customer base was affirmed to have improved in the past 14 months (in the study area), it is also imperative for the establishments to possess the capacity to maintain operation level with a motivated and dedicated workforce. Improved customer base and an efficient workforce are indices that point towards the direction of service management and improved performance for a hotel leading to quality service delivery and guest satisfaction (Nwokorie, Igbojekwe, 2019; Fitsum, 2018; Nwokorie, Ezeibe, 2016; Silvestro et al., 2004; Mei et al., 1999; Gummesson, 1994). Also, periodic training of employees for quality service delivery (as indicated in the study) helps in keeping employees motivated, thus eliminating role conflicts and ambiguity (Nwokorie, Aneke, 2019; Nwokorie, 2017; Ford et al., 2008).

The social relationship between the guest and the guest service provider, in the role theory of Solomon et al. (2006), has been exposed in this present study. For the present study, guest security is an indication of effective service for hotel establishments. The study has revealed a fusion of elegance, service, standard, compe- 
tence, trust, and personalization for guest satisfaction. These service quality indices are significant elements of the role theory that influence consumer behaviour for quality service management and continuous improvement.

Nwokorie and Igbojekwe (2019) found a positive association between guest loyalty and guest security in their study of ten hotels in Owerri, Nigeria. The present study equally indicates guest security with positive responses in the dimensions of service quality. Availability of guest-friendly processes was also indicated in the responses together with a perceived guest value that accompanies it. Bowen and Schneider (2006) viewed guest value as an imperative for successful service management. Guest-friendly processes in the service encounter are also important if guests are expected to feel value for their money (Nwokorie, 2016; Dwyer, Schurr, Oh, 2009). Thus, quality service delivery has not been treated as a mere variable in the study establishment in conformity with Grönroos (2005).

Electronic payment of services and reservations, with the availability of internet services, were positively indicated in the study. Obiora and Nwokorie (2019) found out that tourism destinations' websites have a positive effect on customer perception of service delivery. Hotel guests tend to patronize hotel establishments that are better equipped with an online feedback mechanism that would engender service recovery and guest service management (Obiora, Nwokorie, 2019; Fitsum, 2018; Nwokorie, Ezeibe, 2016; Marshall et al., 2015; Brenner et al., 2006). Thus, hotels are encouraged by the opportunities provided by internet services for continuous improvement on service delivery to maintain a competitive outlook.

Studies have suggested that hotel tariffs should be flexible, with hotels having dedicated customer care units in place, to forestall customer aggression during service failure (Nwokorie, Ezeibe, 2016; Joby et al., 2006; Czepiel, 2004; Johnston, Morris, 1985). In the present study, the availability of a flexible tariff and customer care unit received favourable responses. Regular energy supply, which is a tool for building guest satisfaction (Nwokorie, Igbojekwe, 2019), and reducing service breakdown to the barest minimum (Nwokorie, Adiukwu, 2020; Nwokorie, 2016; Nwokorie, Ezeibe, 2016) was also indicated in the study. Energy inefficiency in service delivery is an index of guest turnover in the service industry as a result of the poor services emanating from service breakdown as observed by Shehu, Inuwa, Husseini and Yakubu (2019), and Bohdanowicz, Churie-Kallhauge and Martinac (2001).

The study also shows that the establishments enjoy guest goodwill through the positive word-of-mouth recorded. Positive word-of-mouth is a means of showing satisfaction for products and services offered by hotel guests and an index of service quality and customer loyalty in hotel establishments (McCallum, Harrison, 2006; Parasuraman et al., 2006a; Swan, Trawick, Silva, 2006). Therefore, the present study has exposed flexible hotel tariffs, dedicated customer care units, and regular energy supply as essential elements of managing the service encounter in the hotel industry for guest satisfaction.

\section{Hypotheses Test Summary}

Results for Correlations, ANOVA, and Ordinary List Squares (OLS) are presented in Table 6. The null hypotheses $\left(\mathrm{H}_{0}\right)$ stated for the study were tested for acceptance or rejection. The hypotheses emanated from the objectives of the study and were employed to assess the relationships between the consequent variables. The decision rule is to accept $\mathrm{H}_{0}$ if the $\mathrm{p}$-value (sig. value) $\geq 0.05$, otherwise $\mathrm{H}_{0}$ is rejected.

\section{Hypothesis One}

The correlation coefficient (-0.694) indicates a strong negative relationship between employees' motivation and quality of service delivery. This suggests that though employees delivered quality services, the motivation from the employer is not enough. Also, about $48.2 \%$ variation in the quality of service delivery can be credited to employees' motivation. The standard error of the estimate is 1.096 with a significant value of 0.028 .

Analysis of variance is needed in investigating whether the regression model is sufficient enough in testing the relationship between the motivation of employees and the delivery of quality services. However, the 
F-value is 9.666 with sig. value of 0.028 which is an indication that the model is sufficient in relating the two variables under consideration. Hence, the study went further to model specification.

The regression model for $\mathrm{H}_{1}$ is specified as:

$\mathrm{QSD}=14.972-0.806^{\star} \mathrm{EM}$

For the model (1), employees' motivation contributes negatively to the quality of service delivery (with coefficient -0.806) and the result is significant. $\mathrm{H}_{1}$ is rejected since the sig. value is less than 0.05 , and the study finds a significant relationship between the motivation of employees and the delivery of quality services.

\section{Hypothesis Two}

The Correlation coefficient (0.543) indicates a weak positive relationship between guest satisfaction and quality of service delivery. This shows that $29.5 \%$ variation in guest satisfaction can be attributed to the quality of service delivery. The standard error of the estimate is 0.922 with a significant value of 0.000 . F-value is 63.186 with sig. value of 0.000 which is an indication that the model is sufficient in relating guest satisfaction and quality of service delivery.

The regression model for $\mathrm{H}_{2}$ is specified as:

$\mathrm{GS}=6.347+0.542^{\star} \mathrm{QSD}$

In the model (2), quality of service contributes positively and significantly to guest satisfaction with coefficient 0.542 and sig. value of $0.000 . \mathrm{H}_{2}$ was rejected since the sig. value is less than 0.05 , and the study concludes that a significant relationship exists between guest satisfaction and quality of service delivery.

\section{Hypothesis Three}

The correlation coefficient of 0.311 for $\mathrm{H}_{3}$ indicates a weak positive relationship between guest goodwill and service management. This shows that a $9.7 \%$ variation in guest goodwill can be attributed to service management. The standard error of the estimate is 0.922 with a significant value of 0.332 . F-value is 0.147 with sig. value of 0.332 which is an indication that the model is neither adequate nor sufficient in relating customer goodwill and service management.

The regression model for $\mathrm{H}_{3}$ is specified as:

$\mathrm{GG}=3.360+0.022 \mathrm{SM}$

The model (3) reveals that service management contributes positively to guest goodwill but it is not significant with coefficient 0.022 and sig. value of 0.332 . The null hypothesis is accepted as the sig. value is greater than 0.05 . Therefore, the study concludes that there is no significant relationship between guest goodwill and service management in the study area.

\section{CONCLUSION AND RECOMMENDATION}

The results of this research have shown a significant association of efficient service management with guest satisfaction. As indicated by Parasuraman et al. (2006a), Grõnroos (2005), and Johnston and Morris (1985) that quality service delivery gives rise to customer fulfilment, this study affirms the association between guest satisfaction and quality of service delivery. This study also gathered that although guest goodwill leads to increased patronage, most guests do not necessarily provide positive word-of-mouth to other people based on 
the available services. In most cases, some guests may decide to advertise the products and services provided by a hotel to others. But, adequate provision of services is a prerequisite for customer goodwill.

By motivating employees to deliver quality services and continuously improve on the quality of service delivery for enhanced guest satisfaction, hotel managers will provide solutions to solving service management and guest satisfaction setbacks for the hotel industry. Further, hotels that ensure guest goodwill, in the long run, are confident to succeed in the competitive business environment.

This study critically attests to the impact of service management on guests' satisfaction. The findings suggest that since employees are required to incorporate their emotional state to the objectives of the establishment and the direct requests of the guest (Hochschild, 2003), the employer needs to provide adequate motivation to enhance workforce dedication for facilitating guest satisfaction.

Management of hotels should ensure that adequate training is provided for employees to foster professional and courteous service to customers as a means of engendering guest satisfaction. Hotels should develop and sustain a service quality model that would help the establishment continually deliver quality products and services to guests as this can help enhance guest satisfaction.

Energy supply should be an essential investment for hotels wishing to maintain a competitive outlook. Since energy supply remains a central problem for most Nigerian businesses, hotels should invest in alternative renewable energy. Such investments will ensure the regularization of energy supply in the hotel industry for optimum performance.

Hotels should provide customer care units where customers can state their grievances to know the areas necessary for improvement. Management should work towards earning guests' confidence. Guest confidence does not only result in guest loyalty. Loyalty helps in setting a good reputation for the hotel establishment. Moreso, hotels should ensure that promises of quality service provision to guests are met to consolidate guests' confidence and enjoy customer goodwill.

Management of hotels should set strategies to gain a competitive advantage over other business rivals, either by lowering prices or providing quality services that justify the high (but affordable) price. Medium hotels should strive to meet guests' expectations by moving along with industry trends, especially information and communication technology. By so doing, competition in the hotel industry would be enhanced to forestall unexpected guest turnover and consequent organizational failure.

\section{REFERENCE}

Abuya, M.B., Shale, N.I. (2018). Role of inventory management practices on performance of the hospitality industry in Kenya. The Strategic Journal of Business and Change Management, 5(2), 1649-1673.

Aluri, A., Munnangi, S.S. (2011). Asset and inventory management in the hotel industry using RFID technology. Retrieved December 14, 2019, from https://scholarworks.umass.edu

Bello, M.B., Bello, Y.O. (2017). Employees' empowerment, service quality and customers' satisfaction in hotel industry. The Strategic Journal of Business and Change Management, 4(4), 1001-1019.

Blake, B.F., Dexheimer, C., Mercurin, N. (2001). Disparity analysis, a double-edged sword, Marketing News, 13 January, pp. 34-35.

Bohdanowicz, P., Churie-Kallhauge, A., Martinac, I. (2001). Energy-efficiency and conservation in hotels Towards sustainable tourism. Proceedings of the 4th International Symposium on Asia Pacific Architecture, Hawai'I

Bowen, D., Schneider, B. (2006). Service marketing and management: Implications for organisational behaviour. Research in Organisational Behaviour, 10, 43-80.

Brenner, M., Garschhammer, M., Hegering, H. (15 August, 2006). When infrastructure management just won't do - The trend towards organizational it service management. In Kern, E., Hegering, H., Brügge, 
B. (eds.). Managing development and application of digital technologies: Research insights in the Munich Center for digital technology \& management, Springer Science \& Business Media, pp. 131-146.

Carev, D. (2008). Guest satisfaction and guest loyalty study for hotel industry. Rochester Institute of Technology, Department of hospitality and service management, Rochester: ProQuestLLC

Çetin, I. (2013). Motivation and its impact on labour productivity at hotel business: A conceptual study. International Journal of New Trends in Arts, Sports \& Science Education, 2(1), 70-79.

Czepiel, J. (2004). Service encounters and service relationships: Implications for research. Journal of Business Research, 20, 13-21.

Czepiel, J.A. (2000). Managing Customer Satisfaction in Consumer Service Businesses. Report No. 80109. Cambridge, MA. Marketing Science Institute.

Dwyer, F.R., Schurr, P.H., Oh, S. (2009). Developing buyer-seller relationships. Journal of Marketing, 51, 11-27.

Evans, B.R., Peterson, B.L., Demark Walinefried, W. (2004). No difference in response rate to a mailed survey among prostate cancer survivors using conditional versus unconditional incentives. Cancer Epidemiol Bio markers \& Preventions, 13(2), 277-278.

Fitsum, G. (2018). Factors influencing employee performance in hotel: A comparative study of government and privately owned hotels in Eritrea. International Journal of Research in Business Studies and Management, 5(11), 1-9.

Ford, N.M., Walker, O.C., Churchill, Jr., G.A. (2008). The psychological consequences of role conflict and ambiguity in the industrial sales force. In K.L. Bernhardt (Ed.), Marketing: 1776- 2008 and Beyond. Chicago: American Marketing Association.

Ghazi, K.M. (2016). Hotel maintenance management practices. Journal of Hotel Management, 5(1), 1-13.

Gong, T., Park, J., Hyun, H. (2020) Customer response toward employees' emotional labor in service industry settings. Journal of Retailing and Consumer Services, 52, 101899.

Grönroos, C. (2005). A service quality model and its marketing implications. Journal of Marketing, 18, 36-44.

Gummesson, E. (1994). Service management: An evaluation and the future. International Journal of Service Industry Management, 5(1), 77-96.

Hassan, M., Hassan, S., Nawaz, M.S., Aksel, I. (2013). Measuring customer satisfaction and loyalty through service fairness, service quality and price fairness perception: An empirical study of Pakistan mobile telecommunication sector. Science International (Lahore), 25(4), 971-980.

Hochschild, A. R. (2003). The managed heart: Commercialization of human feeling. Berkeley, Los Angeles, London: University of California Press.

Joby, J., Grove, S.J., Fisk, R.P. (2006). Improvisation on service performances: Lessons from jazz. Managing Service Quality: An International Journal, 16(3), 247 - 268.

Johnston, R., Morris, B. (1985). Monitoring and control in service operations. International Journal of Operations \& Production Management, 5(1), 332-328

Jomnonkwao, S., Champahom, T., Ratanavaraha, V. (2020). Methodologies for determining the service quality of the intercity rail service based on users' perceptions and expectations in Thailand. Sustainability, 12, 4259. https://doi.org/10.3390/su12104259

Kaplan, R.S. (2003). Measuring manufacturing performance: A new challenge for managerial accounting research. The Accounting Review, 58, 4.

Klaus, P. (2006). Quality epiphenomenon: The conceptual understanding of quality in face-to-face service encounters. In J.A. Czepiel, M.R. Solomon, C.F. Suprenants (Eds), The service encounter: Managing employee/customer interaction in service businesses (pp. 17-33), Lexington: MA. Lexington Books.

Lewis, J., Sauro, J. (2009). The Factor Structure of the System Usability Scale. Proceedings of the 1st International Conference on Human Centered Design: Held as Part of HCI International. 5619. 94-103. https// doi.org/10.1007/978-3-642-02806-9 12

Marshall, T., Mottier E.M., Lewis, R.A. (2015). Motivational factors and the hospitality industry: A case study examining the effects of changes in the working environment. Journal of Business Case Studies, 11(3), 123132. 
McCallum, J.R., Harrison, W. (2006). Interdependence in the service encounter. In J.A. Czepiel, M.R. Solomon, C.F. Surprenant (Eds.), The service encounter: Managing employee/customer interaction in service businesses (35-48). Lexington, MA: Lexington Books.

Mei, A.W.O., Dean, A.M., White, C.J. (1999). Analysing service quality in the hospitality industry. Managing Service Quality: An International Journal, 9(2), 136-143.

Neath, I., Farley, L.A., Suprenant, A.M. (2003). Directly assessing the relationship between irrelevant speech and articulatory suppression. Quarterly Journal of experimental psychology, 56(A). 1269-1278.

Nickson, D., Baum, T., Losekoot, E., Morrison, A., Frochot, I. (2002). Skills, organisational performance and economic activity in the hospitality industry: A literature review. Coventry.

Nwokorie, E.C. (2016). Service recovery strategies and customer loyalty in selected hotels in Lagos State, Nigeria. Net Journal of Business Management, 4(1), 1-8.

Nwokorie, E.C. (2017). Impact of organizational conflict on employee job performance in selected hotels in Lagos Nigeria. International Scientific Journal TURIZAM, 21, (1), 45-64. https://doi.org/10.18421/TRZ21.01-04

Nwokorie, E.C. (2020). Event operation and management: A multidimensional perspective. Kaduna, Nigeria: Hospitality and Tourism Management Association of Nigeria.

Nwokorie, E.C., Adeniyi, E.E. (2021). Tourists' perception of ecotourism development in Lagos Nigeria: The case of Lekki Conservation Centre. International Scientific Journal - TURIZAM, 25(1), 11-30.

Nwokorie, E.C., Adiukwu, K.I. (2020). Hospitality and tourism entrepreneurship: Administrative barriers in Imo State, Nigeria. International Scientific Journal - TURIZAM, 24(1), 13-32. https://doi.org/10.5937/turizam24-22955

Nwokorie, E.C., Aneke, F.O. (2019). Training needs approach for effective employee motivation in the hotel industry for improved productivity. Journal of Pure and Applied Sciences, 1(1), 164-173.

Nwokorie, E.C., Ezeibe, N. (2016). Service failure as a causative of customer aggression on hospitality industry employees. Basic Research Journal of Business Management and Accounts, 5(2), 12-18

Nwokorie, E.C., Igbojekwe, P. (2019). Security challenges for the hotel industry: Implications for selected hotels in Owerri, Nigeria. Academica Turistica - Tourism and Innovation Journal, 12(2), 193-205. https://doi. org/10.26493/2335-4194.12.193-205

Nwokorie, E.C., Obiora, J.N. (2018). Sustainable development practices for the hotel industry in Nigeria: Implications for the Ilaro area of Ogun State. Research in Hospitality Management, 8(2), 125-131. https://doi. org/10.1080/22243534.2018.1553383

Oliver, R. L. (1993). A conceptual model of service quality and service satisfaction: Compatible goals and different concepts. In Swart, T. A., Bowen, D. E., Brown, S. W. (eds.), Advances in Service Marketing and Management, 3, JAI Press, Greenwich, CT, 65-86.

Otu, J.E., Itam, V.A., Emeka, J.O., Eja, E.I. (2013). The catalytic role of hotel industry in human resource development in Calabar, Nigeria. Research on Humanities and Social Sciences, 3(11), 106 - 112.

Parasuraman, A., Zeithaml, V.A., Berry, L.L. (2006a). SERVQUAL: A multi-item scale for measuring consumer perceptions of service quality. Journal of Retailing, 64, 12-40.

Parasuraman, A., Zeithaml, V.A., Berry, L.L. (2006b). A conceptual model of service quality and its implications for further research. Journal of Marketing, 49(Fall), 41-50.

Purohit, G., Purohit, D. (2013). From customer satisfaction to customer delight: A new trend in hospitality industry. Global Journal of Management and Business Studies, 3(5), 545-548.

Schneider, B. A., Pichora-Fuller, M. K. (2000). Implications of perceptual deterioration for cognitive aging research. In F. I. M. Craik, T. A. Salthouse (Eds.). The handbook of aging and cognition, pp. 155-219. Lawrence Erlbaum Associates Publishers.

Shehu, A.I., Inuwa, I.I., Husseini, I.U., Yakubu, I. (2019). Relationship of hotel energy management strategies and hoteliers' perception on sustainable energy management in Abuja Nigeria, Resources and Environment, 9(1), 19-26.

Silvestro, R., Johnston, R., Fitzgerald, L., Voss, C. (2004). Quality measurement in service industries. International Journal of Service Industry Management, 1, 54-66. 
Smith, S. (1982). How to quantify quality. Management Today, October.

Solomon, M., Bamossy, G.J., Askegaard,S., Hogg, M.K. (2006). Consumer behavior: A European perspective 3rd ed. London: Prentice Hall.

Steers, R.M., Braunstein, D.N. (2008). A behaviourally-based measure of manifest needs in work settings. Journal of Vocational Behaviour, 9, 251-266.

Steers, R.M., Spencer, D.G. (1977). The role of achievement motivation in job design. Journal of Applied Psychology, 4, 472-479.

Swan, J.E., Trawick, I.F., Silva, D.W. (2006). How industrial salespeople gain customer trust. Industrial Marketing Management, 14, 203-211.

Tatikonda, L.U. (2013). The hidden costs of customer dissatisfaction. Management Accounting Quarterly, 14(3), 34-43.

Tse, E.C.Y., Ho, S. (2009). Service quality in the hotel industry: When cultural contexts matter. Cornell Hospitality Quarterly, 50(4), 460-474.

Voss, C. (2006). Field service management. In Voss, C., Armistead, C., Johnston, B., Morris, B., Operations management in service industries and the public sector, London: John Wiley \& Sons.

Voss, C., Armstead, C., Johnston, B., Morris, B. (2006). Operation Management in service industries and the public sector. London: John Wiley \& Sons.

Yamane, T. (1967). Statistics: An introductory analysis (2nd Ed.). New York: Harper \& Row.

Yoo, W. S., Back, K. J., Park, J. (2019). Editorial: Analysing emotional labor in the service industries: Consumer and business perspectives. Frontiers in Psychology, 10, 2290. doi.org/10.3389/fpsyg.2019.02290

Zeithaml, V. A., Bitner, M. J., Dwayne, D. G. (2013). Services marketing. Integrating customer focus across the firm, 6th Edition. New York: McGraw-Hill Irwin.

Zeithaml, V. A., Parasuraman, A., Berry, L. L. (1990). Delivering quality service. Balancing customer perceptions and expectations. The Free Press, a division of Macmillan, Inc., New York, Collier Macmillan Publishers, London.

CONFLICTS OF INTEREST The author declared no potential conflicts of interest with respect to the research, authorship, and/or publication of this article. (c) 2021 by the author. This article is an open access article distributed under the terms and conditions of the Creative Commons Attribution (CC BY) license (http://cre-ativecommons.org/licenses/by/4.0/). 